\title{
Rethinking the 'open functional' approach: Ideas, problem pressure and reform in the contemporary welfare state
}

\begin{abstract}
Recognition that welfare states continue to change has fostered debate about the relationship between ideas and policy problems in driving governments towards reform. To move the debate forward, this article proposes a modification of Barbara Vis and Kees van Kersbergen's 'open functional approach'. It first argues that while policy problems may provide 'functional pressure' to reform, this pressure is significant only insofar as inaction would risk electoral punishment. Reform pressure is hence best evaluated with reference to contemporaneous expert advice, public opinion data and the timing of elite and media attention. Second, it suggests that ideas may also lead to parties to act as reform seekers, using policy problems as justification for cherished solutions or long-held programmatic goals. The modified approach is demonstrated through comparative application to two case studies, attempts at pension reform in Sweden and the United States.
\end{abstract}

\section{Introduction}

The 1990s saw the rise of a new orthodoxy in welfare state studies. Building on pathbreaking work by Paul Pierson (1994), this 'new politics of the welfare state' argued that the development of large social programs, and the subsequent adaptation of citizens and interest groups, has reshaped incentives for all political actors (Swank, 2001). In general, such accounts have tended to be stability-centric, viewing change as risky and

This is the author manuscript accepted for publication and has undergone full peer review but has not been through the copyediting, typesetting, pagination and proofreading process, which may lead to differences between this version and the Version of Record. Please cite this article as doi: $10.1111 /$ padm.12414

This article is protected by copyright. All rights reserved. 
difficult, and lacking in theoretical tools to fully explain it (Green-Pedersen \& Haverland, 2002).

While far from being outright dismantled, it is now clear that welfare states have begun to respond, in a variety of ways, to contemporary challenges, such as ageing populations, changing gender roles, rapid technological change, and large scale migration (Hemerijck, 2013; Morel, Palier, \& Palme, 2012; Morgan, 2013).

To fill the theoretical gap, scholars have made progress in outlining gradual, endogenous and ideationally driven modes of change (Streeck \& Thelen, 2005; Jacobs \& Weaver, 2014; Schmidt, 2008). However, the literature still leaves a number of questions not fully answered. First, while scholars have established the importance of ideas, there is still work to be done in showing exactly how they matter in relation to other key variables (Shpaizman, 2014; Carstensen \& Schmidt, 2015; Parsons, 2015). Second, while the 'new politics' scholarship has been criticised for its stability-centric nature, its claim that welfare state reform is often difficult and risky is largely accepted (Starke, 2006). As such, it remains an open question as to exactly why governments continue to engage in reform, given the apparent risks.

In this article, I argue that the 'open functional' approach (OFA), proposed by Barbara Vis and Kees van Kersbergen (2013) represents a novel and viable approach to these questions. The OFA sees welfare state reform as being driven by 'functional pressure', which is created by endogenous or exogenous policy problems that threaten the proper functioning, and even continued existence of a policy system. Ideas are described as 
being pivotal to the linking of problem and solution, but provide little independent impetus for reform.

However, while a valuable advance, the OFA's initial formulation has several shortcomings. First, while Vis and Van Kersbergen effectively describe the translation of existential threats to policy systems, with some modification, the approach could also be applied to cases of less obvious vulnerability. To do so, I build on Vis \& Van Kersbergen's earlier work on 'prospect theory', arguing that functional pressure is better defined as threat of electoral punishment emanating from the maintenance of a policy status quo. Second, 'functional pressure' also requires further specification, especially with regards to identification and measurement. I suggest that it be identified through the examination of contemporaneous expert advice, data on public opinion and the timing and sequence of media and elite attention.

Third, I argue that ideas deserve a more prominent role than Vis and Van Kersbergen are willing to grant. Ideas certainly can provide a cognitive link between problem and solution (Kingdon, 1984). However, I contend that they may also motivate leaders to take on the opportunity afforded to them by policy problems, especially where parties have previously failed to implement core policy goals. In this way, dissatisfaction with the status quo may allow for the return of previously dormant, non-viable or unsuccessful ideas. Finally, I suggest that in seeking to explain both the initial stimulus and the ultimate success or failure of reform, the approach is stretched too far, and risks overlooking key mediating factors. 
This modified OFA is then demonstrated through application to two case studies, from two distinctive welfare states: Swedish pension reform in the 1990s, and the failed 2005 attempt at Social Security reform in the United States. In both cases, while the prospect of funding shortfalls provided a degree of functional pressure, the prominence of several ideas incentivised key actors to view functional pressure as an opportunity, rather than only as a threat.

It is now well accepted in the literature that ideas have 'influence of their own, but not completely by themselves' (Biernacki, 1995, p. 35; in Parsons, 2015). This paper largely agrees with Vis and Van Kersbergen's assertion that scholars should make greater effort at describing a material policy context that exists independent of cognitive beliefs. However, I argue that the inverse also applies: Ideas about policy may exist independent of functional pressure. At times, therefore, ideas shape the influence of policy problems, and not only the other way around.

\section{The open functional approach}

Parsimonious and transferrable approaches to policy change are a) surprisingly rare and b) invaluable. It is for this reason that longstanding modes of analysis, such as Kingdon's (1984) 'multiple streams' framework, are ubiquitous in the literature. At the same time, there remains a need to build on these approaches, to construct finer-grained modes of analysis (John, 2003). In particular, there is a need to do so in ways that shed light on the specific ongoing debates in the public policy and welfare state literatures, 
such as why governments engage in welfare state reform, the nature of the relationship between ideas and interests and the question of how exactly problem pressure is translated into action.

One promising recent attempt at producing such a framework is made by Barbara Vis and Kees van Kersbergen (2013), in the form of their 'open functional' approach (OFA). The OFA was developed for two main purposes. First, it seeks to explain why 'some governments [are] able to push through radical welfare reforms while others, operating in similar circumstances, are not', especially in a context where the risks of shifting the policy status quo are often high (Vis \& Van Kersbergen, 2013, p. 840). Second, it carves out a clearly defined role for ideas in producing and shaping change. In doing so, it attempts to explain the initial stimulus for reform and the reasons for success or failure in one approach.

The OFA presents reform as being initiated by problems, whether exogenous or endogenous in origin, that threaten the proper functioning or continuation of a policy system. For example, in their case study, Vis and Van Kersbergen (2013, p. 849) argue that a fiscal crisis within the Dutch disability insurance scheme 'endangered the entire wage and social security system', and constituted a 'system-wide governability emergency'.

However, while these 'functional' demands may embody a threat to important and popular social programs, the approach is 'open' in the sense that it does not assume that political actors will succeed in restoring policy function, or even that they will 
necessarily respond to threat. Instead, ideas provide a 'link or mechanism between the functional demand and the action', allowing actors, through a process of learning, to see a viable way forward within the constraints provided by 'objective' policy conditions (Vis \& Van Kersbergen, 2013, p. 846).

In this way, Vis and Van Kersbergen (2013, p. 841) take issue with the view that 'ideas by themselves are capable of provoking action' (italics in original). Instead they suggest that ideas can only have influence within the bounds created by functional demands. For example, in their article, they highlight the influence of the 'inactivity/activity ratio' in Dutch disability fund reform. In their view, the ratio acted as a persuasive cognitive frame in building support for a particular kind of action: tightening access to the scheme. However, the acceptance of this problem definition was only possible in the context of the 'emergency' resulting from financial problems within the program.

[Table 1 about here]

Still, the acceptance of an idea does not guarantee success, especially given that welfare state reform regularly involves the imposition of losses on particular constituencies. Hence, the approach also outlines a key role for 'blame avoidance', or the ability to avoid political backlash in navigating often unpopular reforms through the political process (Weaver, 1986). 


\section{Expanding (and limiting) the open functional approach}

The open functional approach is a worthy advance on the existing literature, providing a viable framework with which to draw out interactions between policy problems, ideas and interests. Although such relationships have been a long-standing concern for public policy scholars (Sabatier, 1988; Baumgartner \& Jones, 1993), OFA allows for analysis that captures the multi-sided risks facing governments in relation to the contemporary welfare state.

At the same time, in current form, it also contains several limitations. First, although the 'open' nature of OFA makes it useful as a comparative approach, it is also overly agnostic as to how to evaluate the severity of functional pressure. While it might be relatively obvious that a 'governability emergency' would stimulate action, welfare state reform is certainly not always a response to such crises. Second, as noted by Martin Rhodes (2016) in his review of the book in which OFA is also outlined, while the role given to ideas is clearly defined, it is also too narrow. It has long been recognised that ideas not only shape the range of solutions considered feasible, but also the selection and interpretation of problems in the first place (as per Kingdon, 1984).

In the following section, I seek to correct for these limitations by more specifically defining the concept of 'functional pressure' and expanding the role given to ideas within OFA, while also placing limits on its scope. 


\section{Redefining functional pressure}

While Vis and Van Kersbergen rely on system-threatening problems to drive change in the OFA, their earlier work on 'prospect theory' provides a foundation for explaining a wider array of problem pressure and reform (Vis, 2011; Vis \& Van Kersbergen, 2007). Prospect theory suggests that people are more strongly motivated by losses than they are by gains (Kahneman \& Tversky, 1979). Extrapolated to politics, it predicts that governments avoid risk where they perceive themselves to be in the 'domain of gains', or when the status quo is at least tolerable. This is even the case if there are solutions available that will move the status quo towards their preferences. However, when policy problems create the threat of electoral punishment, governments are more likely to engage in the risky business of reform.

The prospect theory account of reform pressure is both compatible with and an improvement on the notion of 'functional pressure' outlined in the OFA. From this perspective, while functional demands may still provide pressure to engage in reform, they do so not because governments keep the maintenance of policy systems as their foremost goal. Rather, problems induce pressure because governments fear electoral punishment in cases where policy dysfunction imposes direct or indirect losses on the electorate. Conversely, policy problems that threaten the proper functioning of a policy system, but somehow do not provide an electoral threat, are likely to be left to 'drift' (Béland 2007). In other words, the difference between 'emergencies', such as the Dutch 
disability fund or Greek sovereign debt crises, ${ }^{1}$ and lesser problems is one of degree rather than mechanism.

At the same time, even if we recognise electoral threat as the mechanism underpinning functional pressure, there still remains the question of how best identify and evaluate it. Several indicators seem most plausible. First, there are the contemporaneous views of experts or advisers, especially those that gained the attention of policymakers in the lead up to reform. For example, in the Swedish pension case discussed in this paper, a major investigatory committee produced a detailed report in 1990, strongly shaping perceptions of the policy problem among elites (Marier, 2008, p. 120; Pensionsberedningen, 1990). While expert advice will not always gain the attention of the public, inaction in the face of a looming problem or crisis would be courting an increased risk of future punishment.

Second, public opinion data should clearly be examined, where available, with particular attention paid to observable changes over time. Finally, functional pressure may be identified by elite and media attention given to an issue. Attention data (whether identified by volume of proposed legislation, committee hearings on the issue or the content of policy speeches and newspaper articles) can help give a sense of how seriously politicians treated a policy problem, and the extent to which a problem gained salience among the issues competing for time on the public agenda (Jones \& Baumgartner, 2005; McCombs \& Shaw, 1972).

\footnotetext{
${ }^{1}$ Highlighted as an example of functional pressure by Van Kersbergen and Vis (2013, p. 12)
} 
Measuring functional pressure is not an exact science, and the emphasis given to each element will vary from case to case. Sometimes, functional pressure may exist without yet being reflected in public opinion. This is often true for pension reform, where experts and elites generally become aware of the likelihood of funding shortfalls well before beneficiaries experience losses. At other times, it is possible that public opinion may reflect unhappiness over an issue that has not yet grabbed the attention of experts or elites. The possibility of varied responses by elites, experts and the public also speaks to the importance of timing and sequence in any such analysis.

Moreover, although each of these elements can provide evidence of functional pressure, it will also be necessary to place this data in context. For example, different legislative institutions and party systems may mediate or enhance the prospect of blame and the ability to pass blame onto others (Ross, 2000). ${ }^{2}$ It can be expected, for example, that a legislative system with higher numbers of veto players could provide more opportunities for blame avoidance than a more majoritarian system. Similarly, while public opinion data can give a broad sense of the likelihood of electoral punishment, it is also important to consider whether a problem affects a key constituency for a governing party, or, conversely, a voter bloc they are unlikely to compete for. In addition, it is not only the amount of attention that matters, but also its tone. As such,

\footnotetext{
${ }^{2}$ Although this literature is valuable, it should be applied with care in the context of the OFA. For the most part, it has been concerned with electoral punishment and blame avoidance in the context of retrenchment, not in the case of inaction (Ross, 2002; Giger \& Nelson, 2010; Wenzelburger, 2014).
} 
we should discern between moments in which a narrative of 'crisis' emerges and discussions of a more technocratic nature.

\section{Ideational pressure}

Ideas may explain welfare state reform in ways that go beyond providing a cognitive link between problem and solution. It should be recognised that governments may also choose to identify a problem, rather than it being forced upon them by functional pressure. In such cases, action can still be explained through prospect theory. However, it will be ideas, rather than the threat of punishment, that causes dissatisfaction with the status quo.

As will be shown in the case studies, pension reform is a good example of a policy area in which functional pressure may not always be sufficient to explain reform. Although demographic changes provide financial challenges, these are often identified well before the actual onset of funding shortages. Therefore, losses for beneficiaries or taxpayers, and hence electoral punishment, often will not be felt until the current government is out of office. Hence, ideas and policy preferences may be needed to explain the choice to act.

Moreover, parties that were out of power during the development of a system of policy, or that have failed to substantively achieve cherished policy goals, may have strong ideational incentives to attempt reform. For example, in Scandinavia, liberal and conservative parties were often out of government for long periods during the post-war era, and hence had little influence on the development or expansion of key welfare 
programs. As a result, it is little surprise that these parties have looked to engage in reform upon taking back office (Blomqvist, 2004). In other words, ideas may have influence by virtue of being those held by newly powerful actors (Carstensen \& Schmidt, 2015).

This is not to suggest that ideas will always play a role beyond that described in the original OFA. However, tracing their influence and evolution over time (within reason) will aid in discerning whether actors were more strongly motivated by new ideational frames or longer held policy preferences, and whether these ideas gained currency before or after the onset of functional pressure.

Implicit in this expanded role for ideas, is the notion that they come in a variety of types. Hence, I follow Béland and Waddan's (2015) suggestion to 'break down' ideas into more usable categories. Here, I choose to make use of a slightly modified version of the tripartite framework proposed by Mehta (2010), consisting of:

1. Policy solutions

2. Policy theories

\section{Programmatic beliefs}

Policy solutions are simply proposals for action. Being action-based, solutions are not purely cognitive, but are important signifiers of assumptions, beliefs and other kinds of ideas. Moreover, as will be shown in the case studies, commitments to policy solutions can cause and shape action. In other words, solutions might not be beliefs, but they can be believed in. 
Policy theories closely reflect the role of ideas outlined by Vis and Van Kersbergen, and are links between problem and solution, such as assumptions about the behaviour of a target group and the reasons for its potential effectiveness (Daigneault, 2014)

Programmatic beliefs are broader sets of sets of guidelines about the appropriate use of policy instruments and institutions (Campbell, 2002, p.28). For example, as will be described in the case study, President George W. Bush's 'ownership society' concept underpinned a consistent set of proposals across policy areas (Béland \& Waddan, 2007). At the same time, broader sets of ideas (sometimes described as 'paradigms') such as 'New Public Management' or monetarist economic theory can also provide prescriptions for policymakers (Green-Pedersen, 2002; Hall, 1993).

[Table 2 about here]

\section{An expanded and limited open functional approach}

The approach outlined above corrects some of the limitations of the original OFA. First, it identifies a more appropriate link between policy problems and problem pressure, and specifies ways of measuring functional pressure. Second, it outlines an expanded causal role for ideas, arguing that beliefs can also lead political actors to regard the status quo as unacceptable.

Despite these changes, the modified approach remains 'open' in the sense that:

a) It recognises that problems can be exogenous or endogenous in origin, and their potential effects can range in severity, 
b) Neither functional demands nor electoral pressure guarantee action,

c) It is agnostic as to whether ideas or functional pressure have greater influence.

It remains 'functional' in that it recognises that policymakers do face incentives to maintain the proper functioning of policy systems, and that functional demands provide material constraints on the range of actions available to them. However, the account presented here suggests that these incentives exist insofar as functional demands imply the prospect of electoral threat.

At the same time, the modified approach also has more limited ambitions than the original. Here, I use it only to explain the initial decision to reform, and not success or failure. The literature on policy success and failure has greatly expanded in recent years, and recognises the importance of complex interactions between institutions, ideas and strategies (Howlett, 2012). Hence, the risk of stretching a parsimonious approach like OFA beyond its explanatory limits seems too high.

\section{Case studies}

I will now illustrate this modified OFA through its application to two case studies, namely attempts at public pension reform in Sweden and the United States. The aim here is not to demonstrate the superiority of either functional or ideational pressure as 
an explanation, nor to offer new empirical insight to the cases. ${ }^{3}$ Rather, the cases serve as a short demonstration of the value of the modified approach.

The Swedish reform began in 1991, after a period of investigation and debate during the 1980s. The existing ATP system, which was implemented in 1960, was entirely replaced with a new system designed by a cross-party working group. The US reform attempt was led by Republican President George W. Bush, initially in 2001 and then again in 2005. The proposed reform, which eventually failed in Congress, was less a replacement of Social Security, the old-age pension system created in 1935, than an attempt to both secure its fiscal position and integrate a voluntary private investment component.

These cases are appropriate for demonstrating the utility of the modified approach, for several reasons. In both, an ageing population presented a potentially immense functional challenge for governments. Yet, the risks inherent in tackling entrenched, not to mention popular public pension programs are well known (Pierson 1994). At the same time, both programs have a long history of often ideological political struggle, with previous victories being of great symbolic importance for Democrats in the United States and the Social Democrats in Sweden. As a result, there is a need to take into account the ideational context of reform. Finally, the choice of cases provides the opportunity to demonstrate the approach in two very different political and institutional contexts.

\footnotetext{
${ }^{3}$ Both of which have been the subject of extended treatments elsewhere (Béland \& Waddan, 2012; Marier, 2008)
} 
The case studies rely upon data from a variety of sources, including previous academic analyses, contemporaneous newspaper accounts and policy documents. The analysis also makes use of interviews with policymakers and politicians who contributed to these reform attempts, conducted as part of a broader project on the politics of welfare state reform. Eleven interviews were conducted in the United States and nine in Sweden, a selection of which are cited in this paper.

\section{Functional pressure}

Expert evaluations

At the time of reform, both Sweden and the United States faced an ageing population, and hence a likelihood of difficulty in meeting future pension obligations. The scope of these problems is shown in Table 3. The date of the decision to reform is taken to be 1991 in Sweden, when a cross-party Pension Working Group was tasked with designing reform, and 2001 in the US, when President Bush announced his Commission to Strengthen Social Security.

[Table 3 about here]

According to projections presented by Sweden's working group and the Social Security Board of Trustees in the US, Sweden appears to have been facing a slightly more urgent demographic and financial situation. Without policy change, Sweden's reserve fund was predicted to run out in 36 years, while the US fund was predicted have another 39 years before exhaustion. At this time contributions from workers would no longer be 
sufficient to meet obligations to pensioners, and the government would need to find additional revenue to pay benefits.

The scope of the problem was also broadly comparable in the longer term, as the US population was expected to age more quickly between 2010 and 2030 (Figure 1). For this reason, it was projected to face a sharper increase in pension spending than Sweden, when considered over a 25-year period (Table 3, column 4).

[Figure 1 about here]

Although the projections demonstrate clear evidence of the fiscal problem facing both nations, they do not necessarily indicate immediate functional pressure on their own. Both pension schemes contained sufficient funding to pay out benefits for decades, likely putting off citizen losses, and hence electoral punishment, for those who were then in government. In fact, we can observe exactly this in the US. Although the Bushled attempt at reform failed, leaving Social Security in a much worse fiscal position than it was in the mid 2000s, there is no indication that the current generation of political leaders are likely to be punished for their inaction.

At the same time, the Swedish system contained 'self-undermining'4 elements that increased the pressure to reform, in ways that did not occur in the US. Importantly, these provided incentives for the Social Democrats to cooperate with reform of the program, the establishment of which was a cherished political victory (Lundberg, 2001).

\footnotetext{
${ }^{4}$ As per Jacobs \& Weaver, 2014
} 
The first self-undermining feature of the Swedish system was the likelihood that wage growth would gradually weaken its role in funding retirement. At the time, there existed a fixed income 'ceiling', over which taxes were still levied, but benefits were not accrued. As wages grew, this meant that that a gradually higher share of worker income would entail no future benefits, hence incentivising greater reliance on private means of funding retirement (Ståhlberg, 1989).

The non-socialist parties disliked the idea of contributions above the ceiling at all, as the arrangement penalised higher income earners (Pensionsberedningen, 1990, pp. 577578). However, removing or indexing the ceiling to inflation would in fact have worsened the financial position of the program, as doing so would have created additional benefit obligations, without increasing revenue.

At the same time, Social Democratic support for reform was made more likely by the method of calculating benefits (the ' $15-30$ rule'), which disadvantaged their traditionally working-class voter base (Anderson, Blomqvist, \& Immergut, 2008, p. 183). By requiring only 30 years of labour market participation to reach the full benefit level, blue-collar workers were not granted any extra benefits for their generally longer working lives. Moreover, they were also penalised by the calculation of those benefits in relation to the highest 15 years of earnings, as blue-collar wages generally experience less growth over a working life.

Social Security calculates benefits in a similar way (although over 35, rather than 30 years of earnings). However, similar incentives do not appear to have existed for the US 
Democratic Party. For one, the party is less closely intertwined with blue-collar unions, which are also weaker in the United States than in Sweden (Swenson, 2002). Second, voting rates are more highly stratified on the basis of income and education levels in the US, hence reducing the electoral impact of losses imposed on working class voters (Gelman et al., 2008; Dahlberg, 2016).

\section{Public opinion}

Recognition of the challenges facing the two systems was reflected in public opinion. However, this public scepticism was long-standing, and, especially in the US, does not appear to have been worsening in the lead up to reform. Figures 2 and 3 display survey data on US public confidence in Social Security. As shown in Figure 2, the public has consistently expressed scepticism since the system faced funding crises in 1977 and 1983.

[Figure 2 about here]

Swedes also appear to have been sceptical about the long-term future of the ATP program. Polling data is less consistently available than in the US. However, Lundberg (2001, p. 21) cites two polls, one from 1983 and one from 1991, that found more than two-thirds of Swedes believed the system would not pay out promised benefits.

At the same time, survey data on welfare state attitudes in Sweden, while not addressing confidence in the pension system directly, does hint at some rising discontent in the lead up to reform (Table 4). According to the Swedish Welfare State Survey, support for 
increasing spending on pensions and the elderly increased sharply between 1986 and 1992.

[Table 4 about here]

There is little evidence to suggest a similar pattern in the lead-up to the decision to reform in the US. In fact, the Employee Benefit Research Institute surveys, displayed in Figure 3, suggest the reverse: confidence in the program in fact slightly increased in the lead up to the Bush reform effort.

[Figure 3 about here]

\section{Media \& elite attention}

An examination of attention data suggests a much clearer divergence between the two reform efforts. Attention in Sweden rose gradually through the 1980s, reaching a peak just as the decision was made to reform, following the 1991 election. Figure 4 shows a peak in media discussion of the pension system just as the investigatory committee, which had been established in 1984 , reached its conclusion. ${ }^{5}$

\footnotetext{
${ }^{5}$ The initial government directives suggest that the committee (a common tool of policy review and development in Sweden) was established to review the effects of various rule changes, which had made the system more technically complex (Pensionsberedningen 1990, p. 12). However, as the financial position of the system became clearer, the committee's work (and public discussion) appears to have given more concern to its longer-term future.
} 
During this time, Swedish media gave prominent and favourable coverage to several economists who argued for reform (Bröms, 1991; Schuck, 1990; e.g. Södersten, 1991a; 1991b).

[Figure 4 about here]

The Bildt government, a centre-right coalition, came into office in September 1991. Following six years of gradually increasing attention, and the publicity surrounding the pension committee's detailed analysis of the system's failings, it seems unlikely that a new government could have ignored the issue.

In the US, attention grew in a similar way during the late 1990s (Figure 5). Moreover, a Social Security Advisory Council released a gloomy report in 1997, which was followed by a lengthy effort at 'national dialogue' on the issue, led by President Clinton (Elmendorf, Liebman, \& Wilcox, 2001).

[Figure 5 about here]

However, although Bush initiated a Presidential Commission in 2001, he was not able to proceed until 2005 , due to the $9 / 11$ terrorist attacks and the subsequent 'War on Terror'. As a result, elite and media attention cooled between 2001 and 2003. In 2005 Bush and his advisers recognised that they could have directed attention towards a different issue and suffered few consequences (Rove, 2010, p. 409). Instead, Bush made a conscious decision to prioritise Social Security, over immigration, as the major domestic issue for his second term as President. 


\section{Ideational pressure}

I have suggested that the Bildt government faced significant pressure to act in 1991, in ways the Bush administration did not in 2005. However, there is still a place for ideational explanation in the Swedish case. In fact, in both nations, right-of-centre parties were led by their ideas to find dissatisfaction in the policy status quo. However, in the US case, unlike in Sweden, this dissatisfaction led to a long-term effort to undermine the program through the development of specific critiques and policy alternatives.

\section{Historical opposition and preference for private investment}

Both US Republicans and the Swedish non-socialist parties had been dissatisfied with the operation of their respective systems since their inception. In Sweden, the debate over the ATP had been one of the most fractious in its contemporary political history (Heclo, 1974, pp. 228-247). After two elections and a referendum on the issue, the Social Democrats ultimately won a narrow, but cherished victory.

According to the non-socialist politicians who helped design the new reform, resentment still lingered. Bo Könberg, the Liberal Party Minister for Health and Social Security and chair of the Pension Working Group, stated that 'I had been against the ATP system since I was very young' (interview with author, 15 October 2015). Margit Gennser (personal communication with author), the Moderate representative to the working group, held similar views, describing the ATP as 'born in confrontation and strife. It was unjust.' 
US Republicans had little chance of blocking the passage of Social Security in 1935, and so largely assented (Béland, 2005, pp. 83-96). However, prominent members of the party continued to make criticisms of it in the following decades. Barry Goldwater, the party's nominee for President in 1964, was initially in favour of making Social Security voluntary (New York Times, 1963). Ronald Reagan criticised the program during the 1976 presidential primaries for not being as 'invested as [it] could be in the industrial might of America' (Rosenbaum, 1976).

Both suffered political repercusions for making such comments. However, beginning in the 1970s, US conservatives began working to make alternative views on Social Security more acceptable. Over time, largely through think tanks such as the Cato Institute and the Heritage Foundation, they developed a thorough critique of the program, echoing Goldwater and Reagan's preference for voluntarism and private investment (Ferrara, 1980; Weaver, 1982).

President Bush appears to have been personally convinced by this critique. In 1978, while running for a seat in the US House of Representatives, he was quoted as saying 'the ideal solution would be for Social Security to be made sound and people given the chance to invest the money the way they feel' (Stevenson, 2005). In 1997, while Governor of Texas, Bush met privately with representatives of Cato's Social Security privatisation project (Michael Tanner, Cato Institute Fellow, interview with author, 14 April 2015). 
Swedish non-socialist parties had also long preferred private savings to public accumulation (Lindbom, 2001, p. 55). During the 1950s debate, the system preferred by the Moderate and Liberal parties was based upon a voluntary framework. In the 1990s, among the Moderates, especially younger members, there was a desire to move to a fully funded, private system (Margit Gennser, personal communication with author). Swedish conservatives were also well aware of the critiques of public pensions coming out of the United States (Gennser).

\section{Linking problem and solution}

There is little doubt that the building of ideational links between problem and solution was important to the decision to reform in both cases, although in different ways. For US Republicans, the build-up of the Social Security Trust Fund, in which surplus contributions are notionally stored, masked the urgency of the problem. In this view, the build-up had not resulted in meaningful pre-funding of benefits, as many Democrats argued, but instead in additional spending by the federal government (Blahous, 2010, pp. 53-56; Ferrara \& Tanner, 1998, pp. 42-44). Empirically, it is difficult, perhaps impossible, to reliably judge the merits of either position in the US case (Munnell, 2005; Smetters, 2004). ${ }^{6}$ However, like the preference for voluntary programs and private investment, the conservative view of the Trust Fund was an old one, dating back to the establishment of the program (Béland, 2007, p. 25). Importantly, it also acted as a

\footnotetext{
${ }^{6}$ The view generally accepted in Sweden was that its reserve funds had successfully maintained partial pre-funding of benefits (Marier, 2008; Munnell \& Ernsberger, 1989).
} 
justification for the implementation of private investment accounts, and added a sense of urgency to the project: once the program stopped running surpluses (2017, according to 2005 forecasts), the means for funding private accounts was largely gone.

In Sweden, the most influential ideas were not partisan critiques of this type, but consensus problem definitions, built up during the debates of the 1980s. In particular, there was a strong focus on the connection between contributions and benefits. Strengthening this link was one of the directives given to the working group by the government (Pensionsarbetsgruppen, 1994b 15). Jans Bröms, whose book Ur askan av $A T P$ was cited as influential by a number of those in the working group (Gennser; Könberg; Anna Hedborg, Social Democratic representative; interviews with author), had also made this argument (Bröms 1991). For Könberg (interview with author), having 'as much of the thing that you are forced to pay connected...to what you get for it' was fundamental to the Swedish welfare state. However, due to changing demographic and economic conditions, as well as the fixed 'ceiling' on benefits, the ATP no longer held to this standard.

Another policy theory given prominence in Sweden was that the existence of a large pay-as-you-go public pension system disencentivised private savings, rates of which had dropped sharply since the 1960s (Pensionsberedningen 1990, p.85-90). There was also consensus that the system, having being predicated on favourable assumptions, had proven to be overly sensitive to economic and demographic changes (Sunden, 2006). 
In the US, not only was President Bush convinced by the conservative critique, he also made clear links with a broader set of programmatic ideas he called the 'ownership society', which touted the superiority of personal responsibility and market-based social policies (Béland \& Waddan, 2007). The concept was linked to policy proposals not just in Social Security, but health savings accounts, home ownership, school vouchers and tax cuts for small businesses (Office of the Press Secretary, 2004; Paley, 2007).

Not dissimilar ideas were popularised in Sweden by the Bildt government. During the 1980s, the Moderates developed a series of programmatic ideas relating to competition, choice and privatisation (Nilsson, 2003). Upon coming to government in 1991, they sought to implement a 'choice revolution' across a number of policy sectors, including health care and education (Blomqvist, 2004). In both cases, pension reform, especially involving increased emphasis on individual choice and privatisation, fitted well with these broader ideas.

[Table 5 about here]

\section{Conclusion}

In its initial formulation, the open functional approach is a viable, if limited, method of explaining welfare state reform. Specifically, it leaves significant ambiguity as to how to best measure and evaluate functional pressure, as well as envisioning an overly narrow role for ideas, given the findings of the existing literature. 
This paper has sought to redress these limitations. It proposes that functional pressure be measured through the examination of contemporaneous expert evaluations, public opinion data (where available) and the timing and sequence media and elite attention. It is also argued (following Béland and Waddan 2015), that ideas need to 'broken down' into more manageable sub-categories, namely policy solutions, policy theories and programmatic beliefs. Policy theories serve much the same ideational function as described in the original OFA (linking problem and solution). However, the expanded version recognises the capacity for longer-held beliefs and cherished solutions to have significant influence of their own. In this way, ideas may both motivate governments to take on risks and act as 'weapons' for political actors to create suitable conditions for reform (as per Blyth, 2002).

At the same time, while this paper has sought to fill in some of the gaps in the original OFA, it still captures only a sample of a complex array of incentives, constraints and ideas that help shape reform. As such, there is an opportunity to build on the foundations of functional and ideational reform pressure with greater theoretical and empirical detail.

First, there is a need to better integrate understandings of how legislative institutions and party systems may mediate electoral threats and blame avoidance (Ross, 2002; Giger \& Nelson, 2010), as well as the ways in which they shape the production of ideas about policy (Campbell \& Pedersen, 2014). Similarly, understandings of functional pressure could be enhanced by further empirical study of electoral punishment, perceptions of electoral threat and the effectiveness of blame avoidance strategies 
(Wenzelburger, 2014). Finally, it would be worthwhile exploring whether different dynamics exist between the ideas that animate a dissatisfaction with the status quo and those that provide the materials for the construction of reform. If done carefully, it may be possible to at least better link the OFA to explanations for the content of reform and its success or failure.

Vis and Van Kersbergen (2013) rightly urge scholars of ideas to consider functional demands as context for political behaviour in relation to reform, thus helping prevent faulty reasoning regarding the link between ideas, interests and outcomes. At the same time, careful tracing of the ideational context of policy problems can also provide important explanatory value to the analysis of reform. Our interpretation of functional demands may hence be shifted from being viewed as a material pressure to an opportunity or justification. While this will certainly not always be the case, the modified open functional approach allows for the possibility that ideas may drive the decision to reform, rather than only shaping the outcome.

\section{Acknowledgements}

I thank Timothy Lynch, Scott Brenton and Jon Pierre for their input and advice on this project. I would also like to thank the three anonymous reviewers for Public Administration for their highly valuable comments, as well as all those who participated in interviews for this research. I gratefully acknowledge financial support from the Australian Government's Australian Postgraduate Award and from the University of Melbourne's Faculty of Arts Fieldwork Grant. 


\section{References}

Adema, W., Fron, P., \& Ladaique, M. (2011). Is the European welfare state really more expensive? OECD Social, Employment and Migration Working Papers. https://doi.org/10.1787/5kg2d2d4pbf0-en

Anderson, K. M., Blomqvist, P., \& Immergut, E. M. (2008). Sweden: Markets within politics. In D. Béland \& B. Gran (Eds.), Public and private social policy: Health and pension policies in a new era (pp. 169-189). Houndmills: Palgrave Macmillan.

Baggette, J., Shapiro, R. Y., \& Jacobs, L. R. (1995). Poll trends: Social Security - an update. Public Opinion Quarterly, 59, 420. https://doi.org/10.1086/269485

Baumgartner, F. R. \& Jones, B. D. (1993). Agendas and instability in American politics. Chicago: University of Chicago Press.

Béland, D. (2005). Social Security: History and politics from the New Deal to the privatization debate. Lawrence: University of Kansas Press

Béland, D. (2007). Ideas and institutional change in Social Security: Conversion, layering, and policy drift. Social Science Quarterly, 88, 20-38. https://doi.org/10.1111/j.1540-6237.2007.00444.x

Béland, D., \& Waddan, A. (2007). Conservative ideas and social policy in the United States. Social Policy \& Administration, 41, 768-786. https://doi.org/10.1111/j.1467-9515.2007.00584.x

Béland, D., \& Waddan, A. (2015). Breaking down ideas and institutions: The politics of tax policy in the USA and the UK. Policy Studies, 36, 176-195. 
https://doi.org/10.1080/01442872.2014.1000845

Blahous, C. (2010). Social Security: The unfinished work. Stanford: Hoover Press.

Blomqvist, P. (2004). The choice revolution: Privatization of Swedish welfare services in the 1990s. Social Policy \& Administration, 38, 139-155.

https://doi.org/10.1111/j.1467-9515.2004.00382.x

Blyth, M. (2002). Great transformations: Economic ideas and institutional change in the twentieth century. Cambridge: Cambridge University Press.

Board of Trustees of the Federal Old-Age and Survivors Insurance and Disability Insurance Trust Funds. (2001). The 2001 Annual Report of the Board of Trustees of the Federal Old-Age and Survivors Insurance and Disability Insurance Trust Funds. Washington.

Bröms, J. (1991, October 21). Odräglig osäkerhet. Dagens Nyheter, p. A4.

Campbell, A. L. (2011). How policies make citizens: Senior political activism and the American welfare state. Princeton: Princeton University Press. https://doi.org/10.1515\%2F9781400841318

Campbell, J. L. (2002). Ideas, politics, and public policy. Annual Review of Sociology, 28, 21-38. https://doi.org/10.1146/annurev.soc.28.110601.141111

Campbell, J. L., \& Pedersen, O. K. (2014). The national origins of policy ideas: Knowledge regimes in the United States, France, Germany, and Denmark. Princeton: Princeton University Press.

Carstensen, M. B., \& Schmidt, V. A. (2015). Power through, over and in ideas: Conceptualizing ideational power in discursive institutionalism. Journal of 
European Public Policy, 23, 318-337.

https://doi.org/10.1080/13501763.2015.1115534

Dahlberg, S. (2016). Voter turnout in Sweden 1994-2014. Berlin: Friedrich-EbertStiftung.

Daigneault, P.-M. (2014). Puzzling about policy paradigms: Precision and progress. Journal of European Public Policy, 21, 481-484.

https://doi.org/10.1080/13501763.2014.893080

Elmendorf, D. W., Liebman, J. B., \& Wilcox, D. W. (2001). Fiscal policy and social security policy during the 1990s. NBER Working Paper 8488.

Ferrara, P. J. (1980). Social Security: The inherent contradiction. Washington: Cato Institute.

Ferrara, P. J., \& Tanner, M. (1998). A new deal for Social Security. Washington: Cato Institute.

Giger, N., \& Nelson, M. (2010). The electoral consequences of welfare state retrenchment: Blame avoidance or credit claiming in the era of permanent austerity? European Journal of Political Research, 50, 1-23. https://doi.org/10.1111/j.14756765.2010.01922.x

Gelman, A., White, J. K., Park, D., Shor, B., \& Cortina, J. (2008). Rich state, poor state, red state, blue state: Why Americans vote the way they do. Princeton: Princeton University Press. https://doi.org/10.2202/1540-8884.1293

Green-Pedersen, C. (2002a). New public management reforms of the Danish and Swedish welfare states: The role of different social democratic responses. 
Governance, 15, 271-294. https://doi.org/10.1111/1468-0491.00188

Green-Pedersen, C., \& Haverland, M. (2002). Review essay: The new politics and scholarship of the welfare state. Journal of European Social Policy, 12, 43-51. https://doi.org/10.1177/0952872002012001562

Hall, P. A. (1993). Policy paradigms, social learning, and the state: The case of economic policymaking in Britain. Comparative Politics, 25, 275. https://doi.org/10.2307/422246

Heclo, H. (1974). Modern social politics in Britain and Sweden: From income relief to income maintenance. New Haven: Yale University Press.

Hemerijck, A. (2013). Changing welfare states. Oxford: Oxford University Press.

Howlett, M. (2012). The lessons of failure: learning and blame avoidance in public policy-making. International Political Science Review, 33, 539-555. https://doi.org/10.1177/0192512112453603

Jacobs, A. M., \& Weaver, R. K. (2014). When policies undo themselves: Selfundermining feedback as a source of policy change. Governance, 28, 441-457. https://doi.org/10.1111/gove.12101

John, P. (2003). Is there life after policy streams, advocacy coalitions, and punctuations? Using evolutionary theory to explain policy change, Policy Studies Journal, 31, 481-498. http://doi.wiley.com/10.1111/1541-0072.00039.

Jones, B. D., \& Baumgartner, F. R. (2005). The politics of attention: How government prioritizes problems. Chicago: University of Chicago Press.

Kahneman, D., \& Tversky, A. (1979). Prospect theory: An analysis of decision under 
risk. Econometrica, 47, 263-292. https://doi.org/https://doi.org/10.2307/1914185

Kingdon, J. W. (1984). Agendas, alternatives, and public policies. London: Scott, Foresman and Company.

Lindbom, A. (2001). De borgerliga partierna och pensionsreformen. In J. Palme (Ed.), Hur blev den stora kompromissen mojlig? Politiken bakom den svenska pensionsreformen (pp. 50-87). Stockholm: Pensionsforum.

Lundberg, U. (2001). Socialdemokratin och 1990-talets pensionsreform. In J. Palme (Ed.), Hur blev den stora kompromissen mojlig Politiken bakom den svenska pensionsreformen (pp. 8-49). Stockholm: Pensionsforum.

Marier, P. (2008). Pension politics: Consensus and social conflict in ageing societies. Abingdon: Routledge. https://doi.org/10.4324/9780203931219

McCombs, M. E., \& Shaw, D. L. (1972). The agenda-setting function of mass media. Public Opinion Quarterly, 36, 176-187. https://doi.org/10.1086/267990

Mehta, J. (2010). The varied roles of ideas in politics. In D. Béland \& R. H. Cox (Eds.), Ideas and politics in social science research (pp. 23-46). Oxford: Oxford University Press. https://doi.org/10.1093/acprof:oso/9780199736430.003.0002

Morel, N., Palier, B., \& Palme, J. (Eds.). (2012). Towards a social investment welfare state? Ideas, policies and challenges. Bristol: Policy Press.

Morgan, K. J. (2013). Path shifting of the welfare state: Electoral competition and the expansion of work-family policies in Western Europe. World Politics, 65, 73-115. https://doi.org/10.1017/S0043887112000251

Munnell, A. H. (2005). Are the Social Security trust funds meaningful? Center for 
Retirement Research Issues in Brief, 30, 1-6.

Munnell, A. H., \& Ernsberger, N. C. (1989). Public pension surpluses and national saving: Foreign experience. New England Economic Review, March/April, 16-38.

New York Times (1963, November 24). Goldwater Defines ‘Conservatism’, p. 129.

Nilsson, T. (2003). Moderaterna, marknaden och makten - svensk högerpolitik under avregleringens tid, 1976-1991. Huddinge: Samtidshistoriska Institutet, Södertörn University.

Office of the Press Secretary. (2004). Fact sheet: America's ownership society: Expanding opportunities. Washington: The White House. Retrieved from https://georgewbush-whitehouse.archives.gov/news/releases/2004/08/200408099.html

Paley, A. R. (2007, January 25). Bush proposes adding private school vouchers to 'no child' law. Washington Post. Retrieved from http://www.washingtonpost.com/wpdyn/content/article/2007/01/24/AR2007012401982.html

Parsons, C. (2015). Ideas and power: Four intersections and how to show them. Journal of European Public Policy, 23, 446-463.

https://doi.org/10.1080/13501763.2015.1115538

Pensionsarbetsgruppen. (1994a). Reformerat pensionssystem. Stockholm: Socialdepartementet.

Pensionsarbetsgruppen. (1994b). Reformerat pensionssystem biliga A. Stockholm: Socialdepartementet.

Pensionsberedningen. (1990). Allmän pension. Stockholm: Socialdepartementet. 
Peters, B. G., Pierre, J. \& King, D. S. (2005). The politics of path dependency: Political conflict in historical institutionalism. The Journal of Politics, 67, 1275-1300. https://doi.org/10.1111/j.1468-2508.2005.00360.x

Pierson, P. (1994). Dismantling the welfare state? Cambridge: Cambridge University Press.

Rhodes, M. (2016). Comparative welfare state politics: Development, opportunities, and reform. Perspectives on Politics, 14, 262-263. https://doi.org/10.1017/S1537592715004090

Rosenbaum, D. E. (1976, March 5). Social Security a major issue in Florida as primary day nears. New York Times, p. 20.

Ross, F. (2000). "Beyond Left and Right": The New Partisan Politics of Welfare. Governance, 13, 155-183. https://doi.org/10.1111/0952-1895.00127

Rove, K. (2010). Courage and consequence: My life as a conservative. New York: Simon and Schuster.

Sabatier, P. A. (1988). An advocacy coalition framework of policy change and the role of policy-oriented learning therein. Policy Sciences, 21, 129-168. https://doi.org/10.1007/BF00136406

Schmidt, V. A. (2008). Discursive institutionalism: The explanatory power of ideas and discourse. Annual Review of Political Science, 11, 303-326. https://doi.org/10.1146/annurev.polisci.11.060606.135342

Schuck, J. (1990, November 8). ATP kan räddas med nytt system. Dagens Nyheter, p. $\mathrm{C} 2$. 
Shpaizman, I. (2014). Ideas and institutional conversion through layering: the case of Israeli immigration policy. Public Administration, 92, 1038-1053. https://doi.org/10.1111/padm.12112

Smetters, K. (2004). Is the Social Security Trust Fund a store of value? American Economic Review, 94, 176-181. https://doi.org/10.1257/0002828041301939

Social Security Administration. (1997). Report of the 1994-1996 Advisory Council on Social Security. Baltimore: Social Security Administration. Retrieved from https://www.ssa.gov/history/reports/adcouncil/report/toc.htm

Södersten, B. (1991a, July 21). ATP urholkar välfärden. Dagens Nyheter, p. A4.

Södersten, B. (1991b, July 22). Fp värnar godtyckets principer. Dagens Nyheter, p. A4. Starke, P. (2006). The politics of welfare state retrenchment: A literature review. Social Policy \& Administration, 40, 104-120. https://doi.org/10.1111/j.14679515.2006.00479.x

Ståhlberg, A.-C. (1989). Problemen med ATP. Ekonomisk Debatt, 89, 351-362.

Stevenson, R. W. (2005, February 27). For Bush, a long embrace of Social Security plan. New York Times. Retrieved from http://www.nytimes.com/2005/02/27/politics/for-bush-a-long-embrace-of-socialsecurity-plan.html?_r=0

Streeck, W., \& Thelen, K. (2005). Introduction. In W. Streeck \& K. Thelen (Eds.), Beyond Continuity: Institutional change in advanced political economies (pp. 339). Oxford: Oxford University Press.

Sunden, A. (2006). The Swedish experience with pension reform. Oxford Review of 
Economic Policy, 22, 154-158. https://doi.org/10.1093/oxrep/gfj009

Svallfors, S. (2011). A bedrock of support? Trends in welfare state attitudes in Sweden, 1981-2010. Social Policy \& Administration, 45, 806-825.

https://doi.org/10.1111/j.1467-9515.2011.00796.x

Swank, D. (2001). Political institutions and welfare state restructuring. (P. Pierson, Ed.), The new politics of the welfare state (pp. 197-237). Oxford: Oxford University Press. https://doi.org/10.1093/0198297564.003.0008

Swenson, P. A. (2002). Capitalists against markets: The making of labor markets and welfare states in the United States and Sweden. Oxford: Oxford University Press. https://doi.org/10.1093/0195142977.001.0001

Van Kersbergen, K., \& Vis, B. (2013). Comparative welfare state politics: Development, opportunities, and reform. Cambridge University Press. https://doi.org/10.1017/CBO9781139021852

Vis, B. (2011). Prospect theory and political decision making. Political Studies Review, 9, 334-343. https://doi.org/10.1111/j.1478-9302.2011.00238.x

Vis, B., \& Van Kersbergen, K. (2007). Why and how do political actors pursue risky reforms? Journal of Theoretical Politics, 19, 153-172. https://doi.org/10.1177/0951629807074268

Vis, B., \& Van Kersbergen, K. (2013). Towards an open functional approach to welfare state change: Pressures, ideas, and blame avoidance. Public Administration, 91, 840-854. https://doi.org/10.1111/j.1467-9299.2012.02071.x

Weaver, C. L. (1982). The crisis in Social Security: Economic and political origins. 
Durham: Duke University Press.

Weaver, R. K. (1986). The politics of blame avoidance. Journal of Public Policy, 6, 371. https://doi.org/10.1017/S0143814X00004219

Wenzelburger, G. (2014). Blame avoidance, electoral punishment and the perceptions of risk. Journal of European Social Policy, 24, 80-91.

https://doi.org/10.1177/0958928713511282

This article is protected by copyright. All rights reserved. 


\section{Tables}

Table 1 Functional pressure and ideas in Vis and Van Kersbergen's open functional approach

\begin{tabular}{|l|l|l|}
\hline & Function & Causes \\
\hline Functional pressure & $\begin{array}{l}\text { Policy problems that } \\
\text { threaten the proper } \\
\text { functioning of a policy } \\
\text { system }\end{array}$ & $\begin{array}{l}\text { Exogenous events; drift; } \\
\text { policies 'undoing' } \\
\text { themselves }\end{array}$ \\
\hline Ideas & $\begin{array}{l}\text { Persuasive link between } \\
\text { problem and solution }\end{array}$ & $\begin{array}{l}\text { Persuasive problem } \\
\text { definition or frame }\end{array}$ \\
\hline
\end{tabular}

Table 2 Pressures to reform in the modified open functional approach

\begin{tabular}{|l|l|l|l|}
\hline Pressure & Function & Causes & Types and measurement \\
\hline Functional & $\begin{array}{l}\text { Response to } \\
\text { circumstances } \\
\text { that induce } \\
\text { punishment for } \\
\text { remaining at } \\
\text { the status quo }\end{array}$ & $\begin{array}{l}\text { Exogenous } \\
\text { events; drift; } \\
\text { policies } \\
\text { 'undoing' } \\
\text { themselves }\end{array}$ & $\begin{array}{l}\text {-Expert evaluation } \\
\text {-Public opinion } \\
\text {-Elite \& media attention } \\
\text {-Timing \& sequence } \\
\text { Context: were conditions quickly } \\
\text { worsening? Were key } \\
\text { constituencies affected? Mediating } \\
\text { effects of party systems and } \\
\text { legislative institutions. }\end{array}$ \\
& $\begin{array}{l}\text { Status quo } \\
\text { becomes } \\
\text { unacceptable } \\
\text { due to ideas } \\
\text { and } \\
\text { preferences }\end{array}$ & $\begin{array}{l}\text { Persuasive } \\
\text { problem } \\
\text { definition or } \\
\text { frame; ideas of } \\
\text { newly } \\
\text { powerful } \\
\text { actors }\end{array}$ & $\begin{array}{l}\text {-Policy solutions } \\
\text {-Policy theories } \\
\text {-Programmatic beliefs } \\
\text {-Timing } \\
\text { Context: were reforming parties } \\
\text { previously unsuccessful in } \\
\text { implementing policy goals? }\end{array}$ \\
& & &
\end{tabular}


Table 3 US and Swedish pensions system at decision to reform (DTR), intermediate growth assumptions

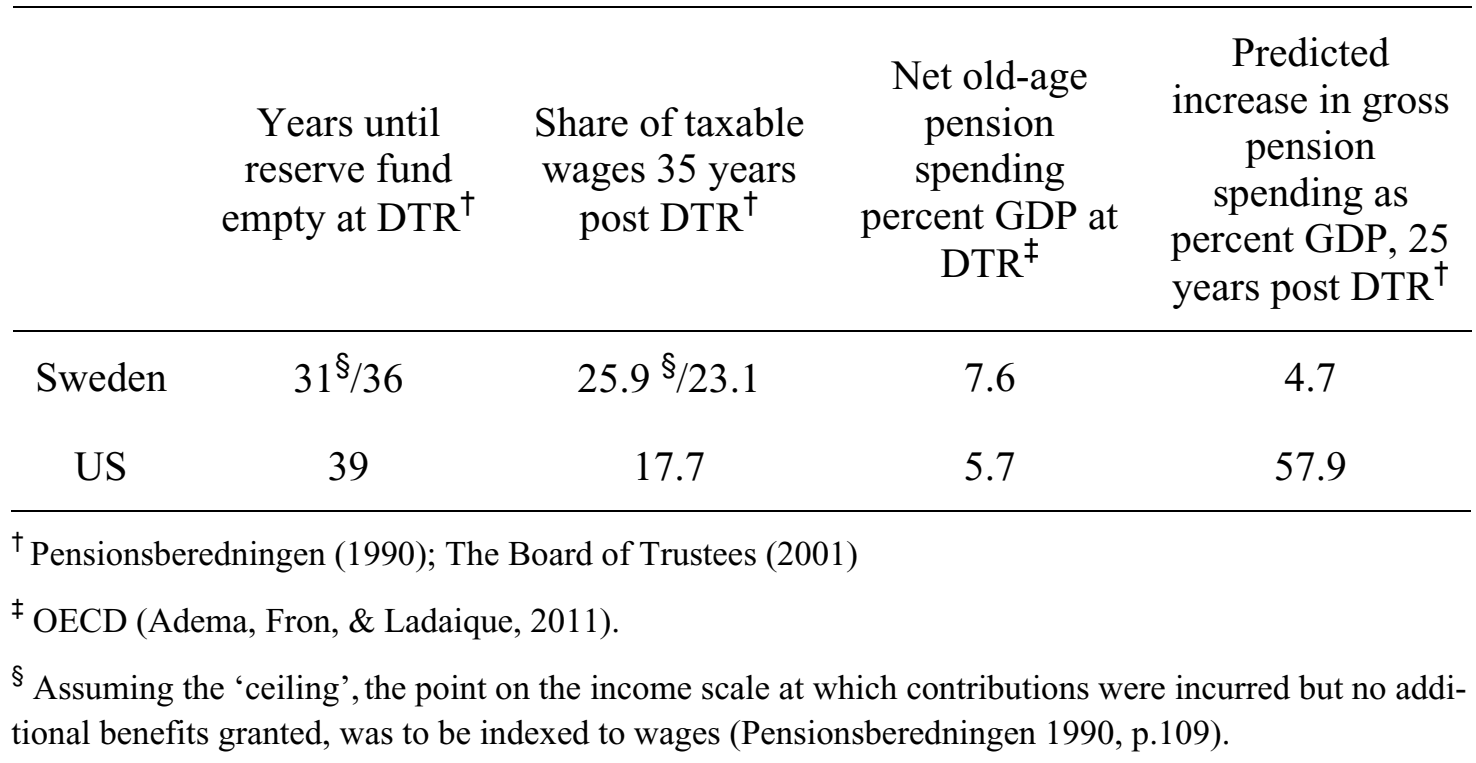

Table 4 Public opinion on Swedish pensions

Do you think that the amount of tax money used for support for the elderly (pensions, elderly care) should be increased, remain the same or decreased? (percent 'increase')

\begin{tabular}{cccccc}
1981 & 1986 & 1992 & 1997 & 2002 & 2010 \\
\hline 30 & 37 & 60 & 70 & 70 & 70 \\
\hline
\end{tabular}

Source: Svallfors (2011) 
Table 5 Summary of ideas with influence on decision to reform

\begin{tabular}{llll}
\hline & US & Sweden \\
\hline $\begin{array}{l}\text { Policy } \\
\text { solutions }\end{array}$ & $\begin{array}{l}\text { Private } \\
\text { accounts }\end{array}$ & $\begin{array}{l}\text { Strong preference for } \\
\text { private accounts among } \\
\text { Republicans }\end{array}$ & $\begin{array}{l}\text { Preference for private } \\
\text { accounts among non- } \\
\text { socialist parties (especially } \\
\text { Moderates). }\end{array}$ \\
$\begin{array}{l}\begin{array}{l}\text { Policy } \\
\text { theories } \\
\text { \& frames }\end{array} \\
\text { Crisis }\end{array}$ & $\begin{array}{l}\text { Trust Fund has not resulted } \\
\text { in savings, therefore fiscal } \\
\text { problem occurs in 2017 }\end{array}$ & \\
& Savings & $\begin{array}{l}\text { Private investment would } \\
\text { yield higher returns }\end{array}$ & $\begin{array}{l}\text { Broad concern regarding } \\
\text { national savings }\end{array}$ \\
& Equity & Intergenerational & $\begin{array}{l}\text { Intergenerational } \\
\text { Connection between fees } \\
\text { and benefits }\end{array}$ \\
\hline $\begin{array}{l}\text { Programmatic } \\
\text { beliefs }\end{array}$ & & 'Ownership society' & 'Choice revolution' \\
\hline
\end{tabular}




\section{Figure Legends}

Figure 1 Percentage of population over the age of 65

Source: Pensionsarbetsgruppen (1994a, p. 16).

Figure 2 Confidence in Social Security 1975-1994

Source: Baggette, Shapiro \& Jacobs (1995). The question asked was 'How

confident are you, yourself, in the future of the Social Security system?'.

Figure 3 Worker confidence in Social Security, 1996-2006

Source: Employee Benefit Research Institute 1994-2006 Retirement Confidence Surveys. Question asked was 'how confident are you that the Social Security system will continue to provide benefits of at least equal value to the benefits received by retirees today?'

Figure 4 Motions presented in Swedish Riksdag on ATP system (left); Articles referring to ATP system in Dagens Nyheter (right) 1980 - 1998

Source: Motions were found via search function of the Riksdagen website (riksdagen.se); newspaper articles found via search of Dagens Nyheter online archive (available at dn.se)

This article is protected by copyright. All rights reserved. 
Figure 5 Congressional hearings on Social Security (left); New York Times articles mentioning 'Social Security' (right), 1980-2006

Source: Data on hearings is taken from the Policy Agendas Project Congressional Hearings Dataset (available at http://www.comparativeagendas.net/); newspaper articles were found via search of the 'ProQuest Newsstand' database

This article is protected by copyright. All rights reserved. 
25

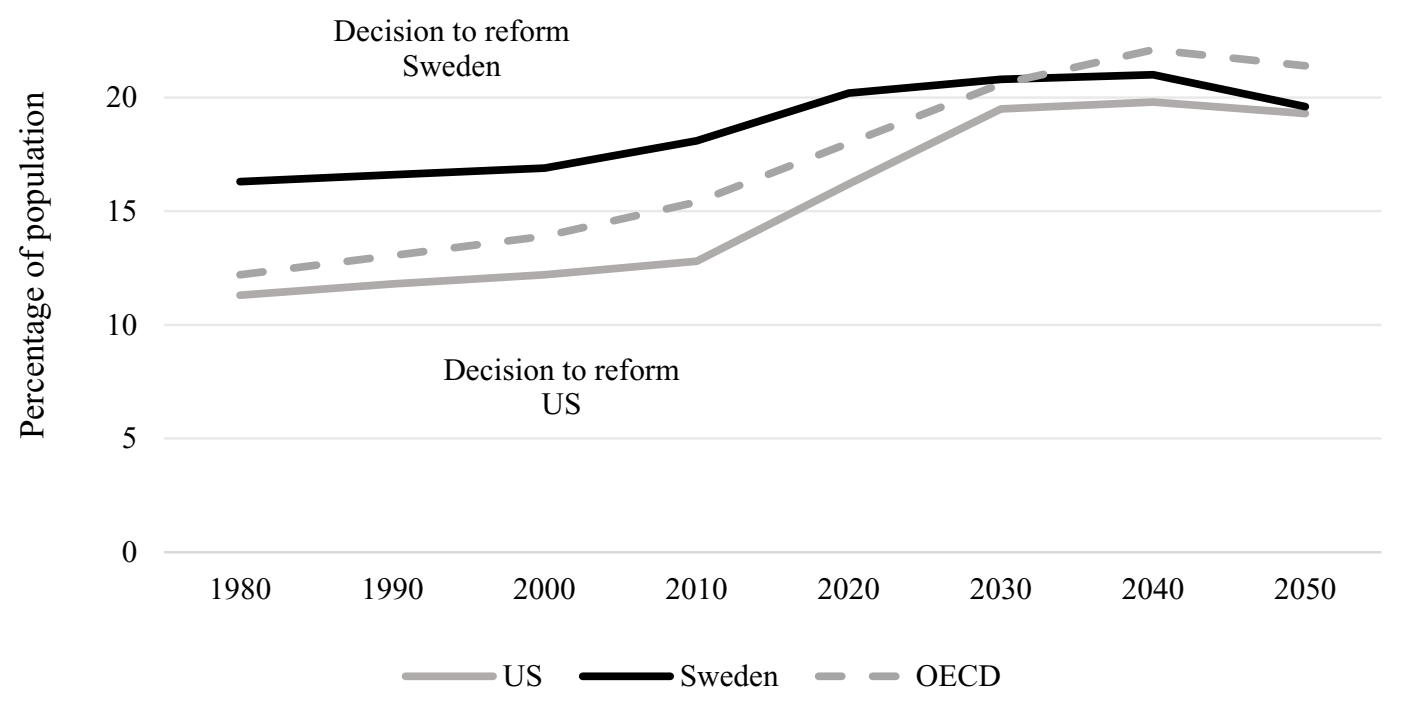

This article is protected by copyright. All rights reserved. 


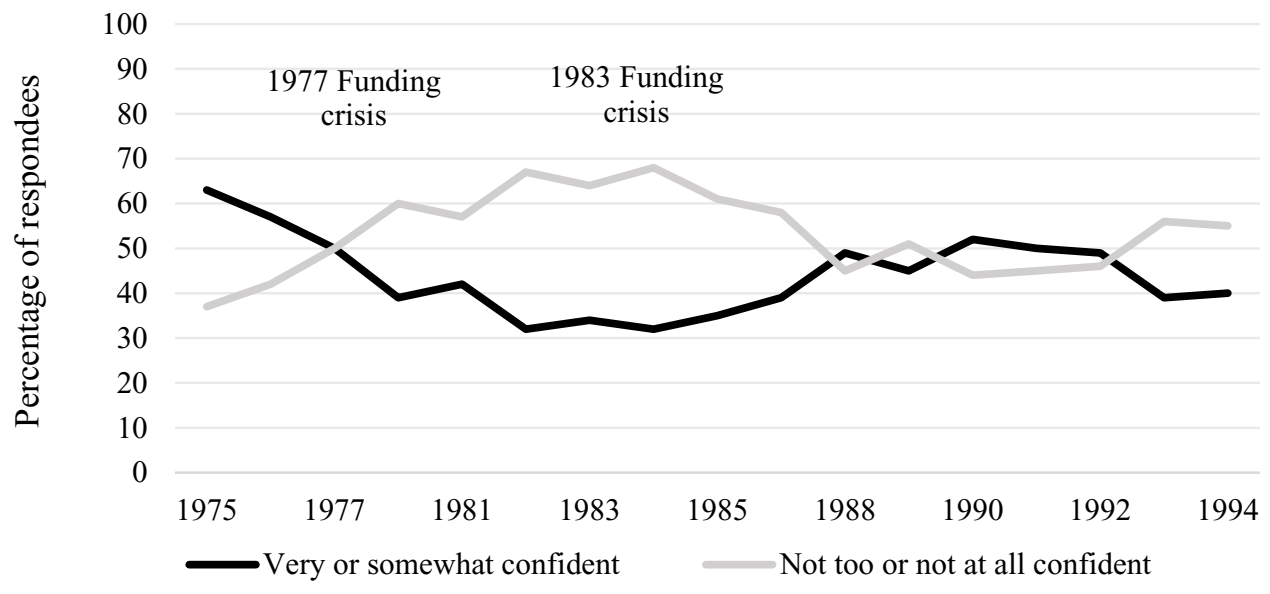

This article is protected by copyright. All rights reserved. 


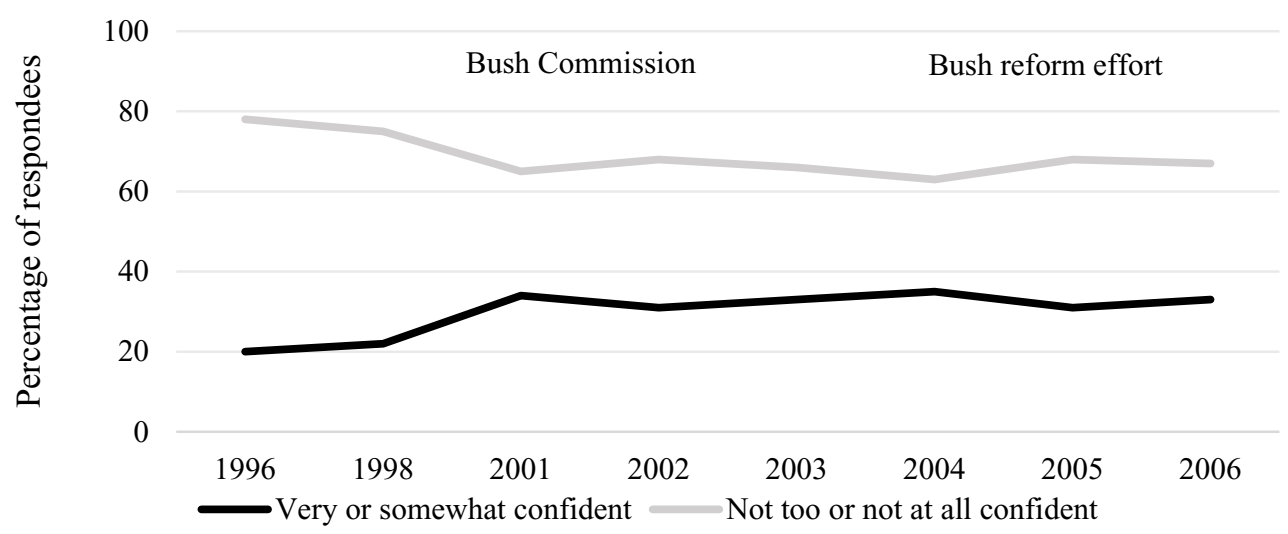

This article is protected by copyright. All rights reserved. 


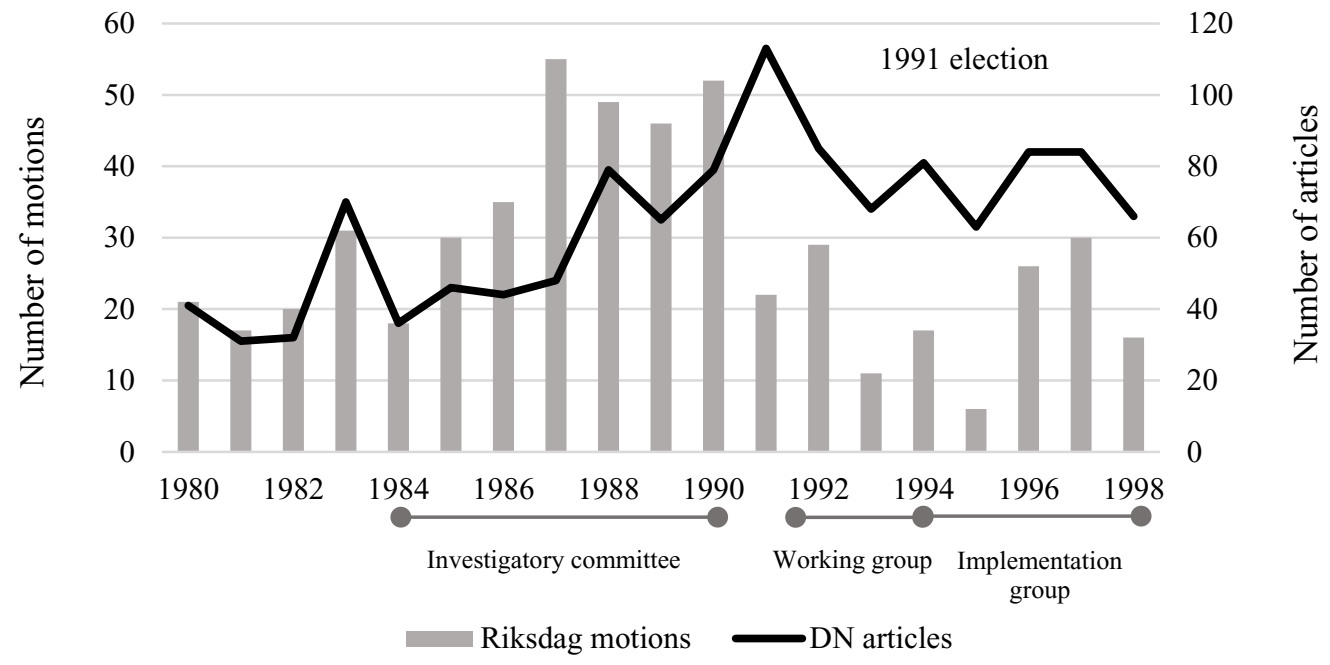

This article is protected by copyright. All rights reserved. 


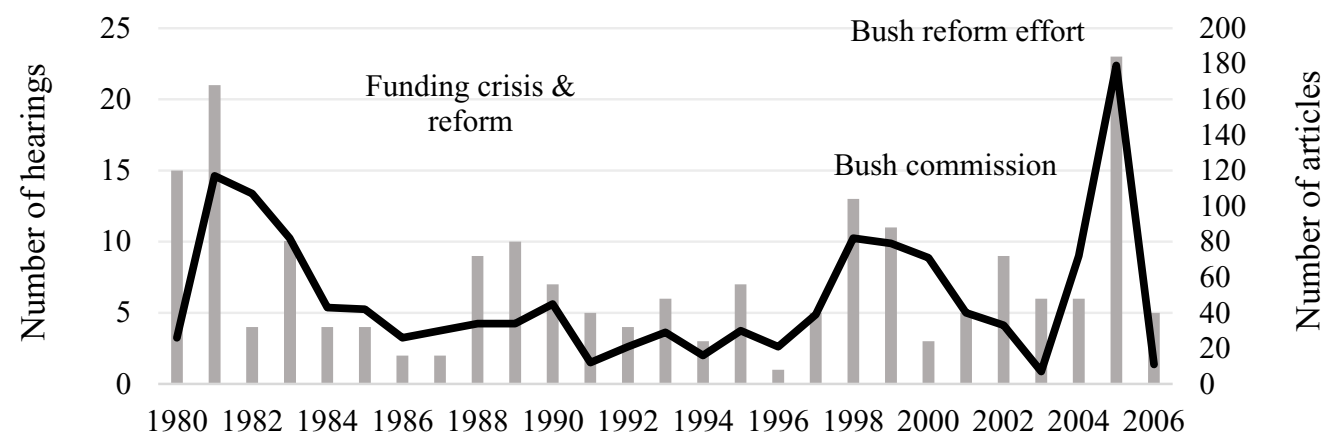

Congressional hearings $\longrightarrow$ NYT Articles

This article is protected by copyright. All rights reserved. 


\section{University Library}

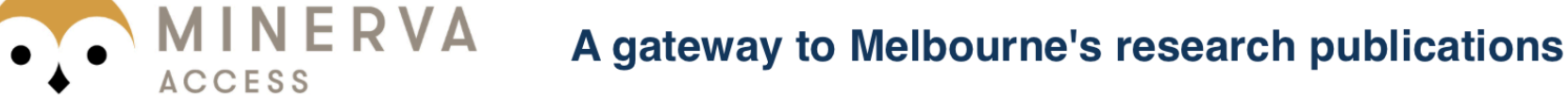

Minerva Access is the Institutional Repository of The University of Melbourne

Author/s:

Hannah, A

Title:

Rethinking the 'open functional' approach: Ideas, problem pressure and reform in the contemporary welfare state

Date:

2018-09-01

Citation:

Hannah, A. (2018). Rethinking the 'open functional' approach: Ideas, problem pressure and reform in the contemporary welfare state. PUBLIC ADMINISTRATION, 96 (3), pp.528-543. https://doi.org/10.1111/padm.12414.

Persistent Link:

http://hdl.handle.net/11343/284508 